\title{
Ganghwaljetongyeum, an anti-arthritic remedy, attenuates synoviocyte proliferation and reduces the production of proinflammatory mediators in macrophages: the therapeutic effect of GHJTY on rheumatoid arthritis
}

\author{
Bo-Ram Jeoung ${ }^{1}$, Kyung Dong Lee ${ }^{2}$, Chang-Su Na ${ }^{3}$, Young-Eok Kim ${ }^{4}$ BoA Kim ${ }^{5}$ and Young Ran Kim ${ }^{1 *}$
}

\begin{abstract}
Background: Ganghwaljetongyeum (GHJTY), a complex herbal decoction, is used to treat rheumatoid arthritis. However, the action mechanism of GHJTY is not still unclear on rheumatoid arthritis. In this study, we examined the beneficial effects and the action mechanisms of GHJTY on synoviocyte proliferation and inflammatory mediators.

Methods: To test the effect of GHJTY on synoviocyte proliferation, HIG-82 cells, rabbit knee synovial membrane cells, were treated with GHJTY under IL-1 $\beta$. To evaluate the effects of GHJTY on proinflammatory mediators, we tested cytokine levels in RAW264.7 cells.

Results: Proliferation of HIG-82 cells was significantly inhibited by GHJTY treatment. We found that GHJTY caused cytoskeleton damage to HIG-82 cells. In contrast, treatment of GHJTY did not show any cytotoxicity to other different origin cell lines, HeLa and RAW264.7 cells. GHJTY inhibited IL-1 $\beta$-mediated NF-KB activation in HIG-82 cells and reduced the LPS-mediated production of proinflammatory cytokines, TNF-a, IL-12, and NO in RAW264.7 cells. In addition, the expression of cyclooxygenase in LPS-activated RAW264.7 cells was also decreased by GHJTY treatment.
\end{abstract}

Conclusions: These results suggest that GHJTY might effectively attenuate rheumatoid arthritis by inhibiting the production of proinflammatory mediators and the proliferation of synoviocytes.

Keywords: Ganghwaljetongyeum, Rheumatoid arthritis, Synoviocytes, Inflammation, IL-1 $\beta$, NF-kB

\section{Background}

Rheumatoid arthritis is a chronic inflammatory disorder accompanied by hyperplasia of the cartilage lining caused by infiltration of inflammatory cells, ultimately resulting in joint damage $[1,2]$. One of the most striking features of inflammatory arthritis is hyperplasia of synovial fibroblasts. Synovitis was reported to play an essential role in the pathophysiology of rheumatoid arthritis [3,4]. The progression of rheumatoid arthritis is accelerated by

\footnotetext{
* Correspondence: kimyr@dsu.ac.kr

${ }^{1}$ Department of Pharmaceutical Engineering, Dongshin University, Naju, Jeonnam 520-724, South Korea

Full list of author information is available at the end of the article
}

proinflammatory cytokines and chemokines, and tumor necrosis factor- $\alpha$ (TNF- $\alpha$ ) and interleukin-1 $\beta$ (IL-1 $\beta$ ) are reported to be associated with the progression of rheumatoid arthritis [5]. In response to these cytokines, synovial fibroblasts proliferate vigorously and form pannus tissues, which destroy the cartilage and bone of the joints [6-8]. Nuclear factor- $\kappa \mathrm{B}(\mathrm{NF}-\kappa \mathrm{B})$ is a transcription factor which regulates gene expression associated with inflammation and is strongly activated by a range of stimuli including TNF- $\alpha$, IL- $1 \beta$, LPS, UV light, and oxidative stress [9]. Cyclooxygenase (COX) is strongly induced by IL- $1 \beta$ and plays an important role in the pathophysiology of rheumatoid arthritis [10]. Therefore, down-regulation of proinflammatory cytokines and NF- $\mathrm{BB}$ may be an 
appropriate therapeutic strategy for rheumatoid arthritis. Antiproliferative agents that modulate synoviocyte growth have been suggested to have potential as anti-rheumatic drugs.

Pain-relieving and nonsteroidal anti-inflammatory drugs (NSAIDs) can help to reduce pain and inflammation in rheumatoid arthritis patients. New approach to the treatment of rheumatoid arthritis has been concentrated to develop safe and potent drugs. Some oriental medicines [11-13] have been used to treat rheumatoid arthritis. Curcumin, a natural product was reported to inhibit inflammatory processes associated with arthritis [14]. Gangwhaljetongyeum (GHJTY), a traditional Korean herbal medicine comprised with several component herbs (Table 1), has been used to treat severe joint pain, limitation of motion, fever, and swelling. In this study, we attempted to evaluate the remedial value and the action mechanism of GHJTY on rheumatoid arthritis by testing its effect on the production of proinflammatory mediators and the proliferation of synoviocytes.

\section{Methods}

\section{Preparation of GHJTY extract}

Herbal medicines used in this study were purchased from Hwalim Natural Drug Co. Ltd (Busan, Korea) and the origins were described in Table 1. The herbal formula of GHJTY (Table 1) was extracted with hot distilled water at $100^{\circ} \mathrm{C}$ for 2 hours at Dongshin University Oriental Hospital (Gwangju, Korea). The extract was centrifuged at $1,500 \mathrm{rpm}$ for $20 \mathrm{~min}$ and the supernatant was concentrated by evaporation under vacuum with preferably low temperature (EYELA, Japan). The concentrated extract was lyophilized by a vacuum freeze drier at $-80^{\circ} \mathrm{C}$ (Samwon Freezing Eengineering Co., Korea).

\section{Cell cultures}

A rabbit knee synovial membrane cell line, HIG-82 (American Type Culture Collection, Manassas, VA, USA), was cultured in Ham's F-12 nutrient mix medium (Ham's F-12, GIBCO, Invitrogen, Carlsbad, CA, USA) supplemented with penicillin-streptomycin and $10 \%$ fatal bovine serum (FBS, GIBCO, Invitrogen) under an atmosphere of $5 \%$ $\mathrm{CO}_{2}$ in a humidified incubator. HeLa and RAW264.7 cells (Korea Cell LineBank, Korea) were maintained in DMEM (GIBCO, Invitrogen) and RPMI (GIBCO, Invitrogen), respectively under above cell culture conditions.

\section{Effect of GHJTY on cell proliferation}

Cells seeded in a 96-well microplate (Corning, NY, USA) at a density of $2 \times 10^{4}$ cells/well were cultured with or without IL-1 $(5 \mathrm{ng} / \mathrm{ml}$ ) (Sigma-Aldrich, Saint Louis, Missouri, USA). Celecoxib (Sigma-Aldrich) was used as a control drug of arthritis. GHJTY or celecoxib was added to the cells for 2 days. Cell proliferation was assayed using 3-(4,5-dimethylthiazol-2-yl)-5-(3-carboxymethoxyphenyl)2-(4-sulfophenyl)-2H-tetrazolium (MTS), according to manufacturer's instructions (Promega, Madison, WI, USA). Absorbance was read by an ELISA microplate reader (Power Wavex340, NIO-TEK-INS TRUMENTS, INC) at $490 \mathrm{~nm}$. Proliferation was calculated as the percentage (\%) to not-treated cells.

\section{Effect of GHJTY on actin cytoskeleton of HIG-82 cells}

HIG-82 cells were seeded in an 8-well glass chamber plate (Nalge Nunc International) at a density of $3 \times 10^{4}$ cells/well and cultured with or without IL-1 $\beta(5 \mathrm{ng} / \mathrm{ml})$ in Ham's F-12 with 10\% FBS for 2 days. After washing with HBSS (GIBCO, Invitrogen), the cells were fixed in $3.7 \%$ formaldehyde for $15 \mathrm{~min}$, permeabilized with $0.1 \%$

Table 1 Prescription of GHJTY in daily doses

\begin{tabular}{|c|c|c|c|}
\hline Drug names & Botanical origin & $\begin{array}{l}\text { Weight } \\
\text { (g) }\end{array}$ & Source \\
\hline $\begin{array}{l}\text { Angelicae Koreanae } \\
\text { Radix }\end{array}$ & $\begin{array}{l}\text { Angelica Koreanum } \\
\text { (Umbelliferae) }\end{array}$ & 6 & Korea \\
\hline Atractylodis Rhizoma & $\begin{array}{l}\text { Atractylodes chinensis } \\
\text { (Compositae) }\end{array}$ & 6 & China \\
\hline $\begin{array}{l}\text { Araliae Continentalis } \\
\text { Radix }\end{array}$ & $\begin{array}{l}\text { Aralia continentalis } \\
\text { (Araliaceae) }\end{array}$ & 4 & Korea \\
\hline Paeonia Radix Rubra & $\begin{array}{l}\text { Paeonia obovata } \\
\text { (Paeoniaceae) }\end{array}$ & 4 & Korea \\
\hline $\begin{array}{l}\text { Stephaniae Tetrandrae } \\
\text { Radix }\end{array}$ & $\begin{array}{l}\text { Sinomenium acutum } \\
\text { (Menispermaceae) }\end{array}$ & 4 & China \\
\hline Clematidis Radix & $\begin{array}{l}\text { Clematis mandshurica } \\
\text { (Ranunculaceae) }\end{array}$ & 4 & China \\
\hline $\begin{array}{l}\text { Angelicae Gigantis } \\
\text { Radix }\end{array}$ & Angelica gigas (Umbelliferae) & 4 & Korea \\
\hline Hoelen & Poria cocos (Polyporaceae) & 4 & China \\
\hline Alismatis Rhizoma & $\begin{array}{l}\text { Alisma orientale } \\
\text { (Alismataceae) }\end{array}$ & 4 & Korea \\
\hline Akebiae Caulis & $\begin{array}{l}\text { Akebia quinata } \\
\text { (Lardizabalaceae) }\end{array}$ & 4 & Korea \\
\hline Citri Pericarpium & Citrus unshiu (Rutaceae) & 4 & Korea \\
\hline Chaenomelis Fructus & $\begin{array}{l}\text { Chaenomeles sinensis } \\
\text { (Rosaceae) }\end{array}$ & 4 & Korea \\
\hline Phellodendri Cortex & $\begin{array}{l}\text { Phellodendron amurense } \\
\text { (Rutaceae) }\end{array}$ & 3 & China \\
\hline Glycyrrhizae Radix & $\begin{array}{l}\text { Glycyrrhiza uralensis } \\
\text { (Leguminosae) }\end{array}$ & 2 & China \\
\hline Juncus Medulla & Juncus effuses (Juncaceae) & 4 & China \\
\hline Gleditsiae Spina & $\begin{array}{l}\text { Gleditsia sinensis } \\
\text { (Leguminosae) }\end{array}$ & 4 & China \\
\hline Lonicerae Caulis & $\begin{array}{l}\text { Lonicera japonica } \\
\text { (Caprifoliaceae) }\end{array}$ & 4 & China \\
\hline Taraxaci Herba & $\begin{array}{l}\text { Taraxacum platycarpum } \\
\text { (Compositae) }\end{array}$ & 4 & Korea \\
\hline Total amount & & 73 & \\
\hline
\end{tabular}


Triton X-100 (Sigma), and incubated in a blocking solution of Image iT signal enhancer (Molecular Probes, Invitrogen) for $30 \mathrm{~min}$. F actin was visualized by Alexa Fluor 594-conjugated Phalloidin (Molecular Probes) as described previously [15]. Confocal images of specimens mounted with a ProLong gold antifade reagent with DAPI (Molecular probes) were acquired using a laser scanning confocal microscope (EZ-C1, Nikon).

\section{Effect of GHJTY on IL-1 $\beta$-induced NF-kB transcription activity in HIG-82 cells}

HIG-82 cells seeded in a 96-well plate (Corning) at $1 \times 10^{4} /$ well were transfected with a reporter plasmid, pNF-кB-luciferase [16] using Hily Max (Dojindo, Japan). One day after transfection, the cells were replaced with fresh Ham's F-12 containing different concentrations of test agents and were incubated for 6 hours. The cells were treated with lysis buffer (Promega) and luciferase activities were assayed by a luminometer (MicroLumat Plus LB96V; Berthold, Wilbad, Germany).

Effect of GHJTY on the production of nitric oxide (NO) and proinflammatory cytokines in RAW264.7 cells RAW264.7 cells seeded at $1 \times 10^{5}$ /well in a 48 -well plate (Corning) were preincubated with GHJTY or celecoxib for 2 hours. LPS (Sigma) was added to the cells for 20 hours. The levels of cytokines, TNF- $\alpha$ and IL-12 were measured in the cell supernatants using sandwich ELISA kits following the manufacturer's experimental protocols (Biolegend, USA). Absorbance was read by an ELISA microplate reader (Power Wavex340, NIO-TEK-INS TRUMENTS, INC) at $450 \mathrm{~nm}$. NO in the culture supernatant was measured using Griess Reagent $(0.1 \% \mathrm{~N}-(1$ naphthyl)-ethylendiamine dihydrochoride, $1 \%$ Sulfanilamide in $2.5 \% \mathrm{H}_{3} \mathrm{PO}_{4}$ ).

\section{Effect of GHJTY on the expression of COX in LPS-activated RAW264.7 cells}

RAW264.7 cells were cultured in a 6-well plate (Corning, USA) at $1 \times 10^{6} /$ well overnight. GHJTY or celecoxib was pretreated to the cells for 2 hours and LPS $(1 \mu \mathrm{g} / \mathrm{ml})$ was added for 18 hours. COX protein was detected by Western blot analysis using an antibody specific to COX-1 (Santa Cruz, USA) and a detection kit, Immobilon Western (Millipore, USA). The relative amount of COX-1 protein was analyzed by LAS-4000 mini (Fujifilm, Japan).

\section{Statistical analyses}

The results are expressed as mean \pm SEM unless otherwise stated. Statistical differences were evaluated using Student's $t$-test, with a $P$ value $<0.05$ considered significant.

\section{Results and discussion}

GHJTY suppresses the proliferation of HIG-82 cells

To assess the effect of GHJTY on synoviocyte proliferation, HIG-82 cells were exposed to IL-1 $\beta$ and GHJTY for 2 days. Cell proliferation was assayed by MTS. IL-1 $\beta$ caused proliferation of HIG-82 cells, which was inhibited by Celecoxib, a non-steroidal anti-inflammatory drug used for the treatment of rheumatoid arthritis. GHJTY significantly suppressed the proliferation of HIG-82 cells at concentrations of 0.3 and $1.0 \mathrm{mg} / \mathrm{ml}$ (Figure 1A). In contrast, GHJTY did not show any cytotoxic effect on other origin cells, HeLa and RAW264.7 cells (Figure 1B
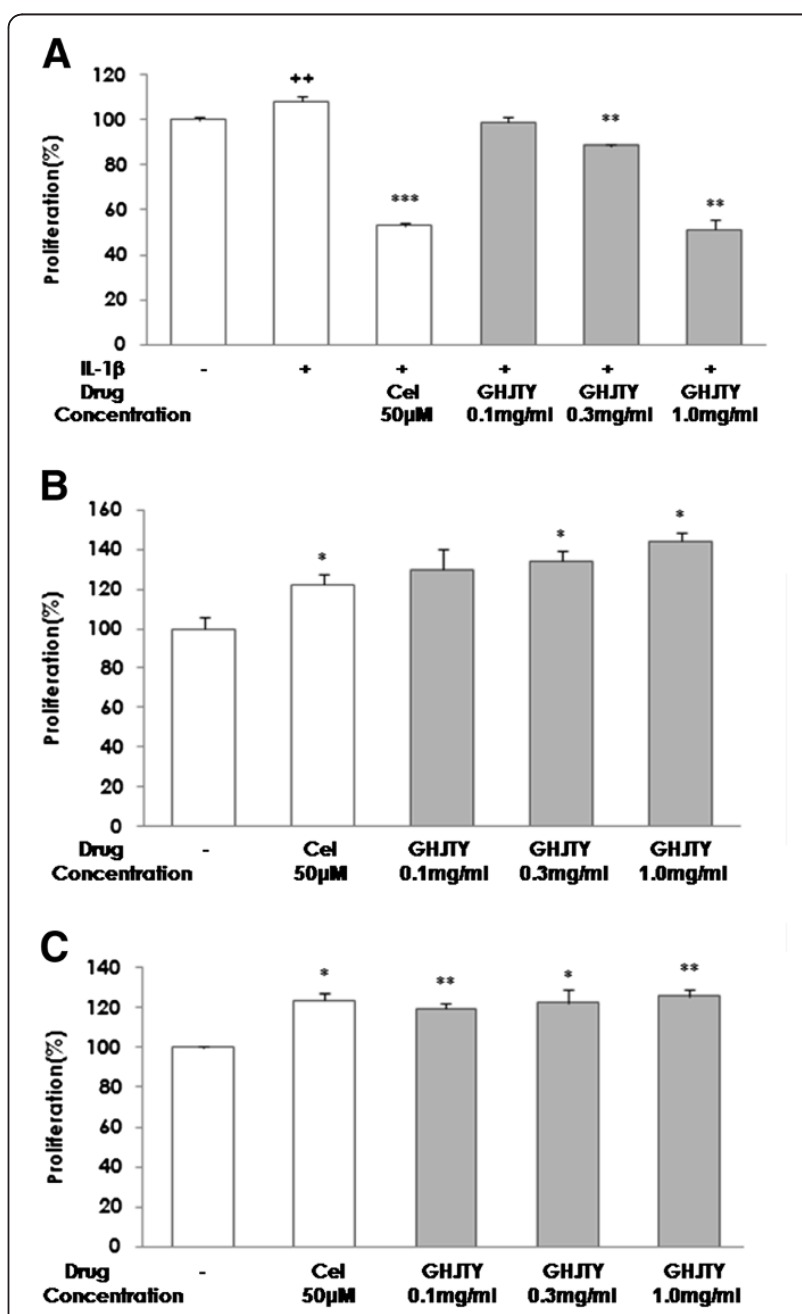

Figure 1 GHJTY specifically inhibits the proliferation of HIG-82 cells. (A) HIG-82 cells were exposed to IL-1 $\beta$ or GHJTY for 2 days and cell proliferation was assayed by MTS. Proliferation of HIG-82 cells was decreased by Celecoxib (Cel). GHJTY significantly reduced the proliferation of HIG-82 cells at concentrations of 0.3 to $1.0 \mathrm{mg} / \mathrm{ml}$. GHJTY did not show any cytotoxic effect on other origin cells, HeLa and RAW264.7 cells (B and $\mathbf{C}$ ). $++P<0.01$ : compared with non-treated group, ${ }^{*} P<0.05,{ }^{*} P<0.01$, and ${ }^{* *} P<0.001$ : compared with IL-1 $\beta$ treated group. 

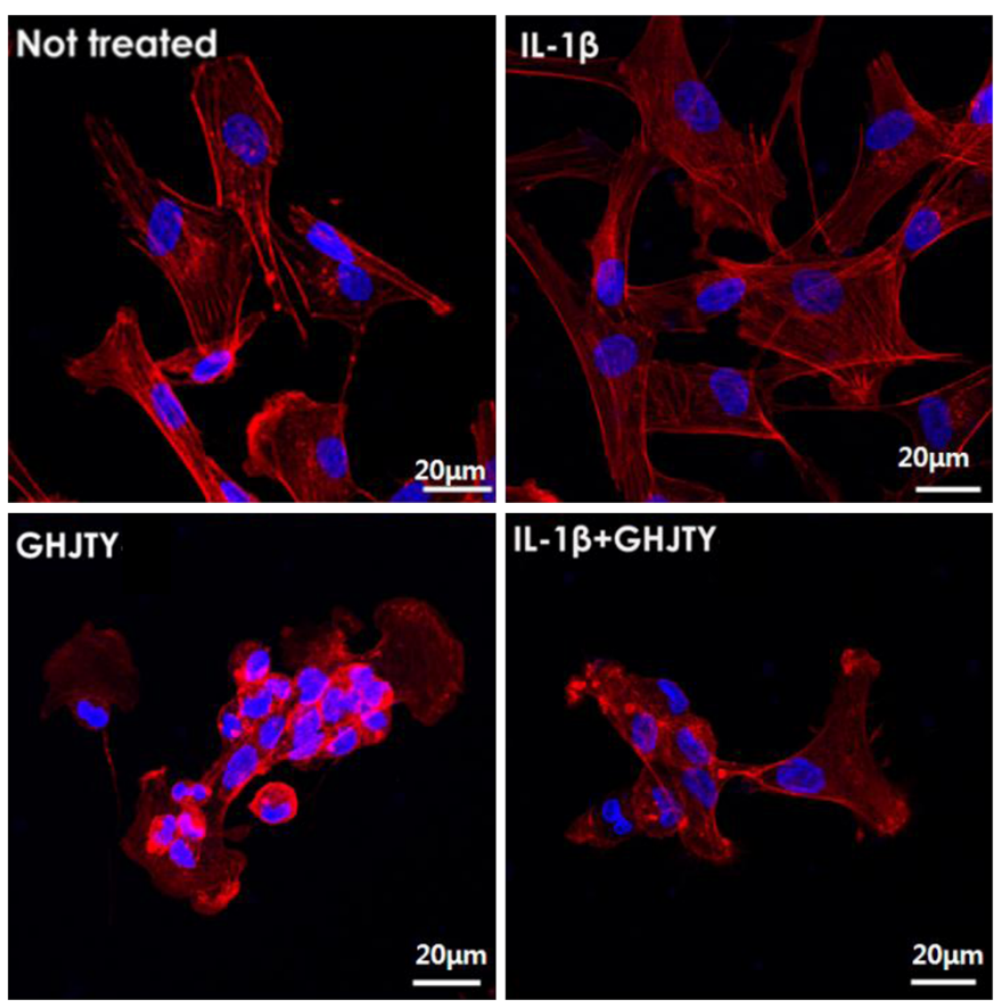

Figure 2 GHJTY causes the rearrangement of actin cytoskeleton in HIG-82 cells. HIG-82 cells were treated with GHJTY for 2 days and actin and nucleus were stained with Alexa Fluor 594-conjugated Phalloidin (red color) and DAPI (blue color), respectively. GHJTY caused the disruption of actin filament in HIG-82 cells and the nuclei of the cells to be condensed. The effect of GHJTY was also shown in IL-1 $\beta$-activated HIG-82 cells.

and 1C). This result suggests that GHJTY has specific cytotoxic activity to synoviocyte HIG-82 cells.

\section{GHJTY causes rearrangement of actin cytoskeleton of HIG-82 cells}

While studying the cytotoxic effect of GHJTY on HIG82 cells, we found that the dying cells became rounded and shrunk. To visualize the morphologic changes of HIG-82 cells, actin and nucleus were stained with Alexa Fluor 594-conjugated Phalloidin and DAPI, respectively. GHJTY caused disruption of actin filaments in HIG-82 cells (Figure 2). Nuclei of HIG-82 cells treated with GHJTY were shown to be condensed (Figure 2). The effect of GHJTY was also shown in IL-1 $\beta$-activated HIG82 cells (Figure 2).

\section{GHJTY suppresses IL-1 $\beta$-induced NF-KB activation in HIG-82 cells}

NF- $\mathrm{kB}$ is a transcription factor involved in inflammation and arthritis. The effect of GHJTY was tested on NF- $\mathrm{kB}$ activation in HIG-82 cells. IL- $1 \beta$ increased NF- $\kappa B$ transcription, which was blocked by GHJTY at a concentration of $1.0 \mathrm{mg} / \mathrm{ml}$ (Figure 3). Celecoxib also blocked the IL-1 $\beta$-induced NF- $\mathrm{kB}$ activation in HIG-82 cells.
GHJTY inhibits LPS-induced production of NO, TNF-a, and IL-12 in RAW264.7 cells

To study the effect of GHJTY on the production of inflammatory mediators, RAW264.7 cells were pretreated with GHJTY for 2 hours and then incubated with LPS for 20 hours. The LPS-induced NO production in RAW264.7

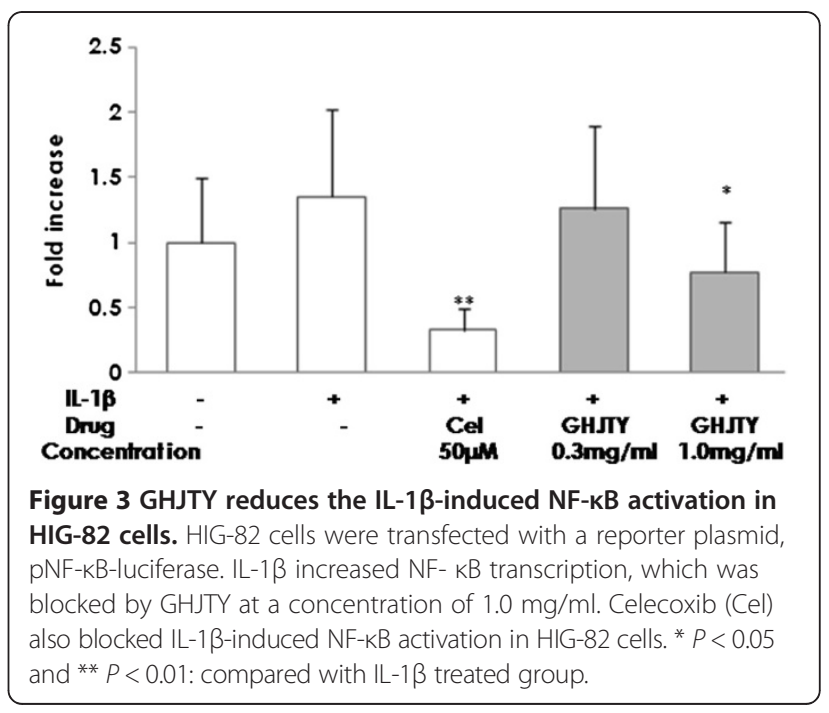


cells was significantly blocked by pretreatment with GHJTY (Figure 4A). In addition, inflammatory cytokines were measured in the cell supernatants by ELISA. GHJTY partly decreased the LPS-induced production of TNF- $\alpha$ and IL-12 cytokines (Figure 4B and 4C).

\section{GHJTY suppresses the COX-1 expression in LPS-activated RAW264.7 cells}

To study the effect on COX-1 expression, GHJTY was treated to the cells for 2 hours and LPS was added for 18 hours. LPS induced COX-1 expression,

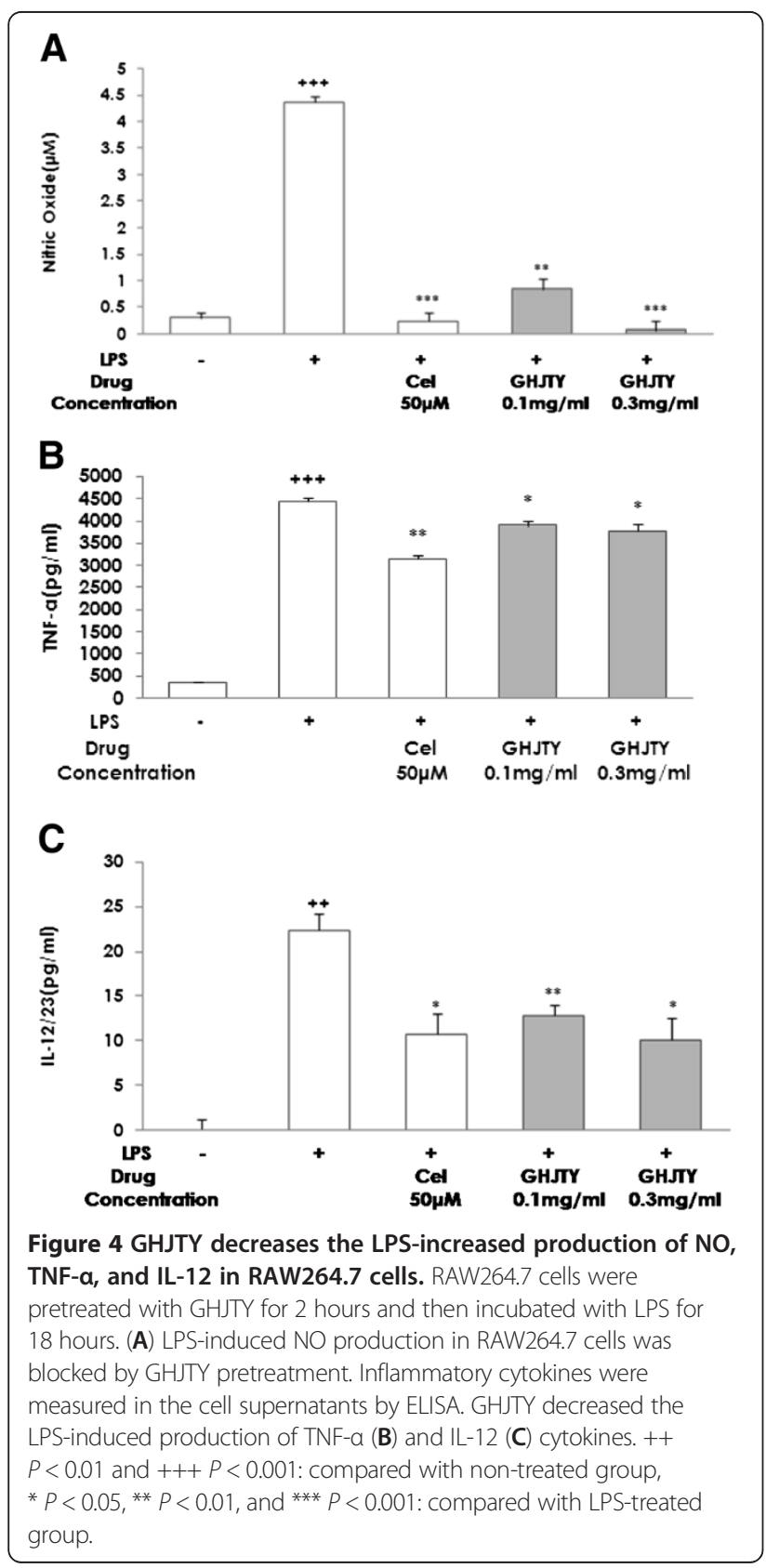

which was reduced by treatment of Celecoxib, a COX inhibitor (Figure 5). GHJTY suppressed the expression of COX-1 in LPS-activated RAW264.7 cells (Figure 5).

\section{Conclusion}

Rheumatoid arthritis is an autoimmune disease characterized by synovial proliferation, infiltration of lymphocytes and macrophage into the synovial lining, and a paucity of apoptosis [6]. We evaluated the remedial value of GHJTY, a prescription for rheumatoid arthritis, by examining its effect on synoviocyte proliferation and inflammatory responses. First, GHJTY significantly inhibited the proliferation of HIG-82 cells, a rabbit knee synovial membrane cell line (Figure 1A) by causing cytoskeleton damage to the cells (Figure 2). In contrast, GHJTY did not show any cytotoxic effects on other origin cell lines, HeLa and RAW264.7 cells (Figure $1 \mathrm{~B}$ and $1 \mathrm{C}$ ). In addition to the inhibitory effect on synoviocyte growth, GHJTY reduced the IL-1 $\beta$ mediated NF- $\mathrm{kB}$ activation in HIG-82 cells (Figure 3). Moreover, GHJTY decreased the LPS-mediated production of proinflammatory cytokines, TNF- $\alpha$, IL-12, and NO in RAW264.7 cells (Figure 4A, 4B, and 4C). The expression of COX-1 in LPS-activated RAW264.7 cells was also reduced by GHJTY treatment (Figure 5). Consequently, GHJTY was shown to be effective in decreasing the hyperplasia of synovial fibroblasts and inflammatory responses, the most striking features of inflammatory arthritis. These results suggest that GHJTY might effectively attenuate rheumatoid arthritis by inhibiting the production of proinflammatory mediators from macrophage-like cells and the proliferation of synoviocytes.

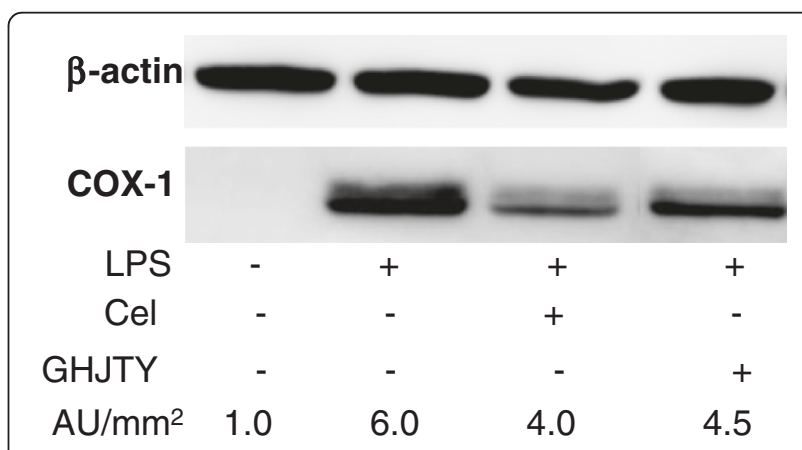

Figure 5 GHJTY reduces the expression of COX-1 in LPS-activated RAW264.7 cells. RAW264.7 cells were pretreated with GHJTY for 2 hours and LPS was added to the cells for 18 hours. $\beta$-actin was used as a control protein. COX-1 was detected by Western blot analysis and the relative amounts were described as $\mathrm{AU} / \mathrm{mm}^{2}$. Celecoxib (Cel) and GHJTY reduced the expression of COX-1 in LPS-activated RAW264.7 cells. 


\section{Abbreviations}

GHJTY: Ganghwaljetongyeum; IL-1 $\beta$ : Interleukine-1 $\beta$; NF-kB: Nuclear factor- KB; LPS: Lipopolysaccharide; TNF-a: Tumor necrosis factor-a; IL-12: Interleukine-12; NO: Nitric oxide; COX-1: Cyclooxygenase 1; NSAIDs: Nonsteroidal antiinflammatory drugs; Cel: Celecoxib.

\section{Competing interests}

The authors have no competing interests.

\section{Authors' contributions}

$\mathrm{BJ}, \mathrm{KDL}$, and BK carried out all the assays. CN and YK participated in the design of the study and performed the statistical analysis. YRK conceived of the study, and participated in its design and coordination and helped to draft the manuscript. All authors read and approved the final manuscript.

\section{Acknowledgements}

This research was supported by the Grant from Graduate School of Dongshin University (Interdisciplinary of Oriental Medicine, Health \& Welfare) in 2011.

\section{Author details}

'Department of Pharmaceutical Engineering, Dongshin University, Naju, Jeonnam 520-724, South Korea. ${ }^{2}$ Department of Oriental Medicine Materials, Dongshin University, Naju, Jeonnam 520-724, South Korea. ${ }^{3}$ College of Oriental Medicine, Dongshin University, Naju, Jeonnam 520-724, South Korea. ${ }^{4}$ Department of Physical Therapy, Dongshin University, Naju, Jeonnam 520-724, South Korea. ${ }^{5}$ Department of Microbiology, Chonnam University Medical School, Gwangju 501-746, South Korea.

Received: 15 December 2012 Accepted: 25 February 2013

Published: 26 February 2013

\section{References}

1. Muller-Ladner U: Molecular and cellular interactions in rheumatoid synovium. Curr Opin Rheumatol 1996, 8(3):210-220.

2. Kramer I, Wibulswas A, Croft D, Genot E: Rheumatoid arthritis: targeting the proliferative fibroblasts. Prog Cell Cycle Res 2003, 5:59-70.

3. Benito MJ, Veale DJ, FitzGerald O, van den Berg WB, Bresnihan B: Synovial tissue inflammation in early and late osteoarthritis. Ann Rheum Dis 2005, 64(9):1263-1267.

4. Hang L, Theofilopoulos AN, Dixon FJ: A spontaneous rheumatoid arthritislike disease in MRL/I mice. J Exp Med 1982, 155(6):1690-1701.

5. Nakamura T, Fujihara S, Yamamoto-Nagata K, Katsura T, Inubushi T, Tanaka E: Low-intensity pulsed ultrasound reduces the inflammatory activity of synovitis. Ann Biomed Eng 2011, 39(12):2964-2971.

6. Park C, Moon DO, Choi IW, Choi BT, Nam TJ, Rhu CH, Kwon TK, Lee WH, Kim GY, Choi YH: Curcumin induces apoptosis and inhibits prostaglandin $\mathrm{E}(2)$ production in synovial fibroblasts of patients with rheumatoid arthritis. Int J Mol Med 2007, 20(3):365-372.

7. Meinecke I, Rutkauskaite E, Gay S, Pap T: The role of synovial fibroblasts in mediating joint destruction in rheumatoid arthritis. Curr Pharm Des 2005, 11(5):563-568

8. Huber LC, Distler O, Tarner I, Gay RE, Gay S, Pap T: Synovial fibroblasts: key players in rheumatoid arthritis. Rheumatology (Oxford) 2006, 45(6):669-675.

9. Dejardin E: The alternative NF-kappaB pathway from biochemistry to biology: pitfalls and promises for future drug development. Biochem Pharmacol 2006, 72(9):1161-1179.

10. Crofford LJ, Wilder RL, Ristimaki AP, Sano H, Remmers EF, Epps HR, Hla T: Cyclooxygenase- 1 and -2 expression in rheumatoid synovial tissues. Effects of interleukin-1 beta, phorbol ester, and corticosteroids. J Clin Invest 1994, 93(3):1095-1101.

11. Liu J, Liu RL: The potential role of Chinese medicine in ameliorating extra-articular manifestations of rheumatoid arthritis. Chin J Integr Med 2011, 17(10):735-737.

12. Keisuke I, Bian BL, Li XD, Takashi S, Akira I: Action mechanisms of complementary and alternative medicine therapies for rheumatoid arthritis. Chin J Integr Med 2011, 17(10):723-730.

13. Funk JL, Oyarzo JN, Frye JB, Chen G, Lantz RC, Jolad SD, Solyom AM Timmermann BN: Turmeric extracts containing curcuminoids prevent experimental rheumatoid arthritis. J Nat Prod 2006, 69(3):351-355.
14. Jackson JK, Higo T, Hunter WL, Burt HM: The antioxidants curcumin and quercetin inhibit inflammatory processes associated with arthritis. Inflamm Res 2006, 55(4):168-175.

15. Kim YR, Lee SE, Kook H, Yeom JA, Na HS, Kim SY, Chung SS, Choy HE, Rhee $J \mathrm{H}$ : Vibrio vulnificus RTX toxin kills host cells only after contact of the bacteria with host cells. Cell Microbio/ 2008, 10(4):848-862

16. Lee SE, Kim SY, Jeong BC, Kim YR, Bae SJ, Ahn OS, Lee JJ, Song HC, Kim JM, Choy $\mathrm{HE}$, et al: A bacterial flagellin, Vibrio vulnificus FlaB, has a strong mucosal adjuvant activity to induce protective immunity. Infect Immun 2006, 74(1):694-702.

doi:10.1186/1472-6882-13-47

Cite this article as: Jeoung et al:: Ganghwaljetongyeum, an anti-arthritic remedy, attenuates synoviocyte proliferation and reduces the production of proinflammatory mediators in macrophages: the therapeutic effect of GHJTY on rheumatoid arthritis. BMC Complementary and Alternative Medicine 2013 13:47.

\section{Submit your next manuscript to BioMed Central and take full advantage of:}

- Convenient online submission

- Thorough peer review

- No space constraints or color figure charges

- Immediate publication on acceptance

- Inclusion in PubMed, CAS, Scopus and Google Scholar

- Research which is freely available for redistribution 